\title{
Jūratė Statkutė de Rosales ir gotų istorija
}

\author{
ZIGMAS ZINKEVIČIUS \\ Lietuvių kalbos institutas, P. Vileišio g. 5, LT-10308 Vilnius \\ El. paštas: vytasz@lki.lt
}

\begin{abstract}
Straipsnyje įvertinamos J. Statkutès de Rosales skleidžiamos idejjos. Siūloma atskirti jos, kaip visuomeninès veikèjos, lituanistinę veiklą, kuri yra teigiama, nuo klaidingos hipotezès apie baltų praeitị. Straipsnyje iškeliamos aikštèn tos hipotezès klaidingos prielaidos, aptariami nemoksliniai jos teiginiai ir populiarumo Lietuvos visuomenéje priežastys.
\end{abstract}

Raktažodžiai: Jūratė Statkutė de Rosales, gotai, gudai

1985 m. Čikagoje pasirodė Jūratės Statkutės knyga Baltu kalbu bruožai iberu pusiasalyje, kurioje ịrodinëjama, kad V-VII a. Ispanijoje ịsigalèję ir ten valstybę ịkūrę gotai buvo ne germanai, bet baltai, kurių kalba esą padariusi dideli poveikị besiformuojančiai ispanų kalbai. Kadangi svarbiausio, galima sakyti, vienintelio, gotų paminklo, vadinamosios Ulfilos (Wulfilos) Biblijos, kalba, be jokių abejonių, yra germaniška (tuo galima ịsitikinti perskaičius jau pirmajji Biblijos sakinį), o ne baltiška, nuo lietuvių kalbos nutolusi daug labiau nei bet kurios seniausios slavų Biblijos kalba, o J. Statkute išvadas dare ne iš lingvistikos (Ulfilos Biblijos kalbos ji netyrè), bet iš ekstralingvistinių duomenų (atsiliepimų apie gotų kalbą istorijos šaltiniuose), tai šiu eilučių autorius $2006 \mathrm{~m}$. pasirodžiusioje savo knygelèje Lituanistikos mokslas ir pseudomokslas J. Statkutės knygą priskyrè prie pseudomokslinių darbų (žr. minètos knygos p. 50-54).

Nuo minètos J. Statkutès knygos pasirodymo praejo jau 26 metai. Per tą laiką autorès požiūris ị knygoje dèstomus dalykus pasikeitè. Tai ji pati pripažįsta. Šiemet pasirodžiusioje jos knygoje Europos šaknys ir mes, lietuviai, kuri čia bus nagrinejjama, autorè rašo: „Praejjus dvidešimčiai metų nuo ano laiko, matau, kad ta „senoji“ mano knyga dabar yra tarsi bevertè, nes daug kas tuomet mano pačios buvo nesuprasta“ (p. 22). Arba vèl: „„_..> buvau padariusi daug klaidų, dalis jų yra ištaisyta“ (p. 23). Kas pakito autorès pažiūrose mums rūpimu klausimu? Iš tikrụjų palyginti nedaug. Dabar J. Statkutè sutinka, kad Ulfilos Biblijos kalba yra germaniška (to toliau neigti nebeįmanoma), tačiau tos Biblijos reikšmę ji stengiasi kiek imanydama sumažinti, ją sumenkinti. Antai rašo: „Ulfilos kalba <...> struktūros požiūriu didele dalimi yra germanų, tačiau leksika - mišinys germaniškų, baltiškų ir slaviškų žodžių" (p. 135; apibendrinimas netikslus ir iš esmès neteisingas). Čia pat dar priduria: „, $<. .>$ galima daryti išvadą, kad Ulfilos kalba buvo naujadaras [priešingai, iš tikruju ji yra labai archajiška, neabejotinas vèlesnių germanų kalbų prototipas - Z. Z.], kuris netrukus išnyko, lygiai kaip sutirpo ir be žinios dingo vadinamieji 'mažieji gotai'“ (taip J. Statkute vadina dabar jos pripažistamus germanus gotus; p. 135). 
Naujoje knygoje toliau tvirtinama, kad gotais amžininkų buvę vadinami gudai - tariamieji baltų protėviai, labai gausi tauta, išplitusi ne tik Rytų, bet ir Vakarų Europoje. Tie gudai (ne germanai gotai!), pasak J. Statkutès, ir sunaikino Romos Imperiją. Be to, jie padarè esminị poveikị Europos kultūros raidai. Tokias pasaulinès reikšmės išvadas autorè daro (germanus gotus paverčia baltais gudais), kaip ir anksčiau, ne tirdama tų tautų kalbos paminklus, ne lygindama juos su seniausiais germanų ir baltų kalbų tekstais (tik taip galima nustatyti tiriamųjų tautų kalbinę priklausomybę), bet spręsdama iš gotų ir kitų ano meto genčių paminèjimų, jų apibūdinimų, esamų amžininkų raštuose. Tie amžininkai, nepaisant jų padèties ano meto visuomenèje, negalèjo turèti kalbinio išsilavinimo šių dienų prasme (kalbos mokslo tada dar nebuvo), kuris leistų jiems išaiškinti kalbų giminystę, jų kilmę ir genetini priklausymą vienai ar kitai kalbu grupei. Jie gentis aptardavo ne lingvistikos (tirdami kalbas), bet ekstralingvistikos (stebėdami tai, kas yra susiję su kalbomis) požiūriu, todèl dažnai tapatindavo net negiminiškas kalbas, jeigu jomis šnekejjusios gentys ịejo ị vieną valstybę ar perimdavo valdžią viena iš kitos: suplakdavo germanus gotus su keltais dakais, prie šių prišliedavo dar trakų šiaurines gentis getus ir pan.

Kaip J. Statkutė, daro visi savamoksliai „kalbininkai“, o kurie iš jų turèjo lakesnę vaizduotę ir buvo drąsesni, tie sukūrè fantastiškas teorijas apie dabartinių tautų ir tų kalbų kilmę. Šiuo atžvilgiu J. Statkutè nèra originali.

Kalbininkai apie senovės genčių ir jų kalbų priklausymą vienai ar kitai giminiškai grupei, kaip minèta, sprendžia iš tų kalbų paminklų, kad ir kokie jie būtų skurdūs (kartais žinomas tik vienas kitas tikrinis vardas), o ne iš amžininkų pasisakymų apie tas gentis ar jų kalbas (tokie pasisakymai gali būti tik pagalbinis šaltinis). Tuo tarpu J. Statkutè net ir nebando ištirti jos vadinamųjų gudų tikrinių vardų, visų pirma asmenvardžių (svarbaus šaltinio apie tų gudų kalbinę priklausomybę), ir iš tokio tyrimo rezultatų daro išvadą apie gudų priklausymą germanams ar baltams. Tirtini asmenvardžiai priklauso senųjų dvikamienių asmenvardžių kategorijai. Tokius turèjo ir baltai, ir germanai. Būtina ištirti tų asmenvardžių sudaromuosius dėmenis ir nustatyti tų dėmenų atitikmenis germanų ir baltų dvikamienių asmenvardžių dėmenų sąvaduose (tokie yra sudaryti ir netgi labai išsamūs). Tik po to galima daryti išvadą apie gudų kalbinę priklausomybę. Deja, J. Statkute šito neatliko.

Ji daugybę kartų tvirtina, kad tie gudai padarè didelị poveikị ispanų kalbai, tuomet dar tik beatsirandančiai iš liaudies lotynų kalbos, bet ir čia šneka bendromis frazėmis: ispanų kalbą ji vadina baltų tarimo iškraipyta lotynų kalba (p. 19, 127), esą ispanų kalba yra paveikta gudų kalbos (151) ir panašiai. Kokiomis konkrečiomis kalbinėmis ypatybėmis reiškèsi tas poveikis, niekur nenurodo. Tik vieną kartą miglotai užsimena apie kažkoki dvibalsiavimą, kurị esą dar reikètų ištirti (p. 128). Jokios kalbinių reiškinių analizès jos knygose visai nèra.

J. Statkutė remiasi žymiaisiais kalbininkais, kalbotyros autoritetais, bet tik tais atvejais, kai jai yra naudinga, nuo skaitytojo nuslèpdama tai, kad tų kalbininkų darbų visuma griežtai prieštarauja jos teiginiams. Kartais tuos kalbininkus net apkaltina nebūtomis nuodèmèmis, pavyzdžiui, Kazimierą Būgą - pangermanizmu. Leisdamas K. Būgos raštus gavau progos susipažinti su visu jo archyvu. İsitikinau šio žmogaus, kaip mokslininko, nepaprastu sąžiningumu. Neaptikau nieko, kas bent „kvepètų“ pangermanizmu.

Kalbėdama apie Paleobalkanų (senąsias Balkanų) gentis ir jų kalbas J. Statkutė noromis nenoromis turejjo susidurti su žymiausiu šių kalbų tyrejju bulgarų kalbininku Ivanu Duridanovu, naudotis jo darbais. Tačiau tai daro taip, lyg žymusis mokslininkas pritartų jos išvadoms. Iš tikrųjų I. Duridanovo pažiūros kalbamuoju klausimu skiriasi kaip dangus ir 
žemè nuo J. Statkutès pažiūrų. Tuo ịsitikinau ne tik studijuodamas jo veikalus (su juo susirašinèjau nuo 1969 m.), bet ir daug kartų su juo kalbėdamasis, ypač 1988 m., kai jis mokslo tikslais lankèsi Vilniuje.

Yra pareikšta nuomonè, kad J. Statkutė esanti žymiosios lietuvių mokslininkès Marijos Gimbutienès idẻjų tęsẻja. Bet tai netiesa. Jų abiejų tyrimo sritys ir mokslinès pažiūros visai skirtingos. Kitokio masto ir abi asmenybès. Tai pripažista pati J. Statkutė (žr. p. 2021), aprašydama savo apsilankymą pas M. Gimbutienę 1975 m. Kalifornijoje, kai nesulaukè pritarimo savo idejjoms ir grižzo į Karakasą nusivylusi. Prof. M. Gimbutienė daugiausia tyrė senosios Europos kultūrą, kokia ji buvo dar prieš ateinant indoeuropiečiams, taigi ir baltams (gaila, tie jos veikalai neišversti $\mathfrak{i}$ lietuvių kalbą), o tai neịeina $\mathfrak{i}$ J. Statkutès tyrimų sferą. Lygiai taip pat M. Gimbutienei nerūpejjo J. Statkutės požiūris ił gotus ir tariamuosius baltus gudus. Apskritai gotai buvo M. Gimbutienès interesų periferijoje, jais domèjosi tik epizodiškai. Tuo ịsitikinau ne kartą kalbėdamasis su M. Gimbutiene, kai ji lankėsi Vilniuje ir skaitè paskaitas Vilniaus universitete 1981 m., taip pat kitomis progomis, ypač 1985 m. lankydamasis pas ją Kalifornijoje, kurị laiką net svečiuodamasis jos viloje užmiestyje ir bute Los Andželo priemiestyje Tapangoje, kur teko pagyventi kelias dienas. 1986 m. ji svečiavosi pas mane Vilniuje. Labai daug kalbejomès. Neatsimenu, kad Profesorè bent kartą būtų užsiminusi apie J. Statkutę ar jos skelbiamas idejjas. Tą patị turiu pasakyti ir apie J. Statkutès minimą Profesorès mokinị Jules (Džulsą) Leviną, kurị gerai pažįstu ir su kuriuo teko daug bendrauti ne tik tada Kalifornijoje, bet ir Vilniuje, kur jis ne kartą lankèsi. J. Statkutès gudai jam, kaip ir Profesorei, visiškai nerūpejjo.

Kas kita J. Statkutès ne kartą minimi Česlovas Gedgaudas, išleidęs knygą Mūsų praeities beieškant, ir Aleksandras Račkus, knygos apie Gudonus autorius, kurių skelbiamos idejjos iš tikrųjų yra artimos J. Statkutės pažiūroms ir su kuriais daug kas ją sieja. Jie visi trys sudarè tikrai vieną „mokyklą“.

Savamoksliai „kalbininkai“ yra pamėgę pasakojimus apie lietuvių protėvių tariamą klajojimą po pasaulį. Kur tik, pasak jų, mūsų protèviai nèra buvę: bastėsi po visus žemynus, gal tik išskyrus Ameriką ir Australiją. Bet toks klajojimas nesuderinamas su lietuvių ir kitų baltų kalbų archajiškumu, kuris įmanomas tik tūkstantmečius ramiai gyvenant nuošaly nuo svetimų genčių, su jomis nesimaišant. Tai suprato J. Statkutė ir, priešingai negu Č. Gedgaudas ir A. Račkus, vengia kalbėti apie „nereikalingus“ mūsų protèvių klajojimus. Naujoje knygoje yra tik vienas miglotas fragmentèlis apie tai, kad maždaug 1260 m. prieš Kristų gudai pasiekè šiaurès vakarų Indiją (p. 142), ir tai esą paaiškina sanskrito atsiradimą (!). Kad gotai, pasitraukdami nuo Baltijos, su savimi išsivesdavo kažkiek vakarinių baltų, tokį faktą mokslininkai (daugiausia Vladimiras Toporovas) jau seniai konstatavo. Tačiau taip atsitikdavo tik su atskiromis žmonių grupèmis, bet ne su visa tauta, kaip tvirtina fantazuotojai.

Nustatant senovès tautų kalbinę priklausomybę labai svarbūs yra žodžių (tiek tikrinių, tiek ir bendrinių) etimologiniai tyrimai. J. Statkutès etimologijoms būdingos savamokslių „kalbininkų“ dvi ryškiausios etimologizavimo ypatybès: 1) apie žodžių kilmès tapatybę sprendžia iš skambejimo panašumo (pvz., Skandija ir skandinti, p. 33), neištyrusi žodžio istorijos, ir 2) nepaiso ankstesnių tiriamojo žodžio etimologijų, paskelbtų net žymių etimologų, paprasčiausiai juos nutyli (pvz., Gdansko, vok. Dancigo siejimo su gotų vardu, p. 35 ir kt., atvejis). Be to, kalbos faktus J. Statkutè neretai dirbtinai tempia prie etimologizuojamo žodžio, kartais net pati juos sukuria. Antai vestgotus (vakarų gotus) ji vadina dirbtiniu terminu vese gudai, kurio žodị nebuvèlị vese sieja su tariamu latvių (ir net prūsų) žodžiu vaciai 'vakariniai' (p. 116, 123). Bet tokio žodžio vakarams pavadinti, aiškiai paliudyto, latvių (juo 
labiau prūsų) kalboje iš tikrųjų nèra, tai pačios J. Statkutės sukurtas žodis. Jeigu žodị vacis latviai ir būtų turejję (dabar tesako vācietis = lie. vokietis), tai reikšmė 'vakarai' jam greičiausiai būtų buvusi svetima. Panašiai J. Statkutė ostgotus (rytų gotus) vadina aušros gudais, žodị aušros siedama su lietuvių kalboje nesamu žodžiu auš(te)ros, esą latvių austrums atitikmeniu (p. 116). Neleistinas kalbos faktų tampymas savo idèjai „sutvirtinti““

Taigi ir naujoje J. Statkutès knygoje yra nemaža kalbinio diletantizmo, būdingo pseudolingvistikai. Kalbininkams ši knyga ateityje galès būti naudinga nebent tuo, kad J. Statkutè, aprašydama istorijos šaltiniuose esamus gotų ir kitų kalbų paminẻjimus, ypač susijusius su Ispanija, šalia vertimo pateikia ir citatas originalo kalba, kuriose esamos tikrinių vardų formos pravers kalbininkų onomastikos studijoms. Žinoma, jeigu originalo citatos yra tikslios (to reikia tikètis).

J. Statkutès populiarumą Lietuvoje, ypač tarp nespecialistų, lėmė susiklosčiusi jai palanki situacija. Sovietinè okupacija žiauriomis priemonėmis išugdẻ lietuvių sąmonèje nevisavertiškumo ir atsidavimo „vyresniajam broliui“ kompleksą, kurị toliau palaiko tebeklestintis pas mus sovietinis kosmopolitizmas, skatinamas proteguojamų naujų globalistinių nuotaikų, ypač „reformuotoje“ mokykloje, iš kurios išguitas Tẻvynès meilès ugdymas ir patriotizmas. Prisideda taip pat kai kurių istorikų vykdomas, ypač per žiniasklaidą, Lietuvos didingos istorijos neigimas ir senosios lietuvių kultūros menkinimas bei niekinimas (galbūt inspiruojamas iš užsienio?). Visam tam atsvarą žmonès mato J. Statkutės idejjose, kuriomis nekritiškai ir besąlygiškai tiki, o pačią J. Statkutę laiko tautos didvyre. Prisiminkime situaciją XIX a., kai lietuvių kalbos niekinimui atsvarą sudare tokie absurdiški pasakymai kaip ir Rojuje lietuviškai kalbèjo.

Visa tai susuko galvas ne tik šiaip jau žmonėms, bet ir kai kuriems mokslininkams, taip pat mokslo vadovams. Jie ėmé globoti J. Statkutę, rūpintis jos knygų leidimu bei jų propagavimu. Belieka su Ciceronu sušukti: O tempora, o mores! (Kokie laikai, kokie papročiai!).

Gauta 20111118

Priimta 20111231

\section{Jūratė Statkutè de Rosales and the history of the Goths}

\section{Summary}

The article addresses the hypothesis raised by the author, according to which the Balts rather than the Germanic tribes destroyed the Roman Empire, founded a state of the Goths in Spain, etc. The absurd conclusions follow from the false methodology: instead of researching linguistic monuments, she grounds her conclusions on the accounts of contemporaries on the nations of that time, the origins of which were not yet possible to explain in that period. The article also deals with the reasons behind the author's popularity in Lithuania.

Key words: Jūratė Statkute de Rosales, Goths, Belarusians 